\title{
Compulsory Education Reform between the Profession and Policy in the Light of Justice and Equal Opportunities
}

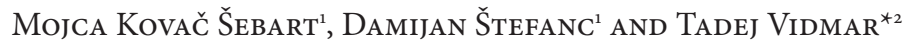

$\approx$ Following the adoption of the conceptual design proposed by the White Paper in 1995 and the legislation adopted on this basis, the reform of primary school transformed its overall image. In the present paper, we discuss only some of the solutions and consider the events and changes that have occurred in the last twenty years, devoting special attention to the systemic, programme and process levels. At the systemic level, where the starting point was primarily to ensure justice and equal opportunities, we have managed to maintain an adequate public network and programme structure, despite various attempts to implement the solutions indicated in the White Paper of 2011, and notwithstanding interventions in the system that were not in fact always well thought out. Nonetheless, more attention should have been paid to reducing inequalities related to sociocultural circumstances and different regions in Slovenia. On the programme level, a consensus needs to be reached on what quality general education means to us; this would alleviate conflicting demands placed on teachers, students and planners of programme solutions. On the process level, however, we find that there is a lack of adequate professional support and systematic evaluation studies, as the quality of school cannot be judged solely on the basis of results from international research. In order to take a step forward on the process level, there is need for quality school-linked school policy that is based on various professions and aimed at raising quality rather than at self-promotion and budget cutting in the field of education.

Keywords: compulsory education, systemic solutions, White Paper, general education, process solutions, programme reform, quality, reform processes

1 Faculty of Arts, University of Ljubljana, Slovenia.

$2{ }^{\star}$ Corresponding Author. Faculty of Arts, University of Ljubljana, Slovenia; tadej.vidmar@ff.uni-lj.si. 


\section{Reforma osnovne šole med stroko in politiko v luči pravičnosti in enakih možnosti}

Mojca Kovač ŠEbart, Damijan Štefanc in Tadej VidmaR

$\approx$ Reforma osnovne šole po sprejetju konceptualne zasnove v Beli knjigi leta 1995 in na tej podlagi sprejete zakonodaje je preoblikovala njeno celotno podobo. $\mathrm{V}$ tem prispevku obravnavamo le nekatere rešitve in tematiziramo dogajanje oziroma spremembe, ki so nastale $\mathrm{v}$ zadnjih dvajsetih letih. Posebej obravnavamo sistemski, programski in procesni sklop. Na sistemski ravni, na kateri je bilo izhodišče predvsem zagotavljanje pravičnosti in enakih možnosti, nam je kljub različnim poskusom uveljavljanja rešitev, ki so se nakazovale v Beli knjigi iz leta 2011, in tudi dejansko ne vedno dovolj premišljenih posegih v sistem uspelo ohraniti ustrezno javno mrežo in programsko sestavo. Ne glede na to pa bi morali več pozornosti nameniti zmanjševanju neenakosti, ki so vezane na socialno-kulturne okoliščine in različne regije v Sloveniji. Na programski ravni je treba doseči konsenz glede tega, kaj nam pomeni kakovostna splošna izobrazba; to bi omililo nasprotujoče si zahteve do učiteljev in učiteljic, učencev in učenk ter načrtovalcev in načrtovalk programskih rešitev. Za procesno raven pa ugotavljamo, da nimamo ustrezne strokovne opore niti sistematičnih evalvacijskih študij, saj kakovosti šole ni mogoče presojati le na podlagi rezultatov iz mednarodnih raziskav. Da bi na procesni ravni naredili korak naprej, potrebujemo kakovostni šoli zavezano šolsko politiko, ki se bo oprla na različne stroke in ji bo cilj dvig kakovosti, ne pa samopromocija in varčevanje s proračunskimi sredstvi za področje vzgoje in izobraževanja.

Ključne besede: osnovna šola, sistemske rešitve, Bela knjiga, splošna izobrazba, procesne rešitve, programska reforma, kakovost, reformni procesi 


\section{Introduction}

In Slovenia in the early 1990s, there was a thorough expert review of the conceptual and systemic solutions that make up the Slovenian education system. This formed the basis for the preparation of legal and curricular or programme solutions, including solutions for compulsory education: a systematic process of monitoring schools was established, funds were provided for financing evaluation studies, and conceptual reflection was undertaken on determining and ensuring the quality of the education system. The legislation also opened the space for the professional autonomy of pedagogical workers on the procedural level (Krek, 1995; Pluško et al., 1999, 2001; Organisation and Financing of Education Act, 1996; Compulsory School Act, 1996).

In the present paper, we review some of the solutions from that time as well as the chronology of and reasons for their modification. We deal separately with systemic, programme or curricular, and procedural solutions, assuming that both White Papers on Education in the Republic of Slovenia, from 1995 (Krek, 1995) and 2011 (Krek \& Metljak, 2011), respectively, provide a comprehensive expert design for systemic solutions for compulsory education. Those who subsequently prepared programme documents, especially national syllabi, then indicated what knowledge should be acquired by new generations of students in public compulsory education by establishing goals, standards of knowledge and proposed content. Evaluation studies, as well as monitoring undertaken by experts from the National Education Institute of Slovenia, should have systematically and comprehensively engaged with the process aspect, on the understanding that the quality of teaching, knowledge transfer and education in classrooms and schools cannot be judged only on the basis of the quantitative collection of opinions of various stakeholders in the educational process.

All of the solutions followed from the reflection that school is an institution that is closely integrated into the social environment, into a hierarchical social structure, and that it is significantly influenced by the circumstances and relationships of the particular society. It was assumed that the primary task of compulsory education is to impart knowledge, and that it is a case of transferring knowledge from generation to generation regardless of which knowledgerelated epistemological and didactic paradigm we advocate, or which concept or strategy we have an affinity for in this reflection (Vidmar, 2011).

The first White Paper (Krek, 1995) after Slovenian independence placed the acquisition of a quality general education and the moral educational dimension of school based on human rights and tolerance among the most important goals of the education system. It was based on an understanding that 
the demands that we place on students regarding knowledge are legitimate and necessary, and that these demands must be accompanied by high expectations of the state, school, teachers and parents. In this regard, it is the responsibility of the state to ensure all students conditions that enable them to meet these expectations and requirements, regardless of their personal circumstances (Kovač Šebart \& Štefanc, 2017a, p. 128).

\section{Systemic solutions of nine-year compulsory education}

The White Paper (Krek, 1995), published on the conclusion of public debate in January 1995 (Kovač Šebart, 2002), presents the principles and theoretical starting points of the education system in the Republic of Slovenia: the points of departure are the principles of democracy, autonomy and equal opportunity (Ibid., p. 15; Kovač Šebart, 1998). According to the Universal Declaration of Human Rights (2018, Art. 26), everyone must have the right to education, which is why at least compulsory education must be financed from public funds. Education must be oriented towards the complete development of the human personality and the consolidation of human rights and fundamental freedoms (Ibid.). In designing an education system, it is also necessary to take into account the specific social conditions and developmental aspirations associated with the requirements for quality and non-repressive school. At the same time, it is emphasised that the education system must enable the achievement of internationally comparable standards of knowledge (Bahovec Dolar et al., 1995). The same starting points or principles were confirmed sixteen years later in the new White Paper (Krek \& Metljak, 2011).

The systemic solutions for compulsory education were designed, supplemented and substantiated at a number of expert meetings between 1992 and 1994 (Marjanovič Umek \& Kovač Šebart, 1995) and formed the basis for the preparation of the new school legislation that was adopted in 1996. The key systemic solutions of nine-year compulsory school (Ibid.) were: entering school at the age of six, structuring compulsory education into three rounded educational periods, descriptive assessment of knowledge in the first educational period and simultaneous descriptive and numerical assessment of knowledge in the second educational period; greater differentiation, including the introduction of streaming within the framework of flexible differentiation from the $4^{\text {th }}$ grade onwards and the introduction of partial external differentiation in the $8^{\text {th }}$ and $9^{\text {th }}$ grades (with well-considered and formally established safeguards against the concomitant drawbacks, cf. Kovač Šebart, 1999); selectivity or elective subjects were enabled in the third educational period; national external assessment of 
knowledge at the end of each educational period; and systemic integration of children with special needs (Kovač Šebart, 2002). Justice and ensuring genuine opportunities for students to acquire knowledge and optimal personality formation were important starting points for finding systemic solutions, and the profession agreed virtually unanimously that Slovenia needs to retain a developed public network of schools and build upon its quality (Ibid.).

This was a time of successful endeavours of school policy, resulting in increased budget funding for the education system and a significant rise in teachers' salaries, as well as in the demand for the university education of teachers. Today, it cannot be reasonably disputed that during this period the already developed network of public kindergartens and schools managed to be retained in the new state and its development was facilitated, at least at a basic level. The scenario could have been completely different: the disintegration of the public network of kindergartens and schools; public programmes in the hands of private providers; competition that only apparently provides selectivity and equal opportunities, as children who do not live in larger cities would be nowhere near having equal conditions for inclusion in a quality kindergarten and compulsory school; social differentiation at the institutional level; marked differences in teachers' salaries, etc. We have been able to witness all of this in the countries of the former Yugoslavia (Jerončić, 2016; Inequality in Croatia, 2016; Poverty and inequality, 2015). However, we must not forget that we have had to deal with such tendencies in the school field throughout the post-independence period. They are significantly strengthened by the (also neoliberal) ideology of free choice and offer, the need for competition, etc. (Kovač Šebart, 2012, p. 3).

School legislation was prepared in accordance with the solutions of the White Paper (Krek, 1995). The experts who prepared the initial argumentation for the individual solutions were known to both the expert public and the general public, as their names were not concealed (Marjanovič Umek \& Kovač Šebart, 1995, pp. 124-125), a practice that was no longer retained after 2004.

With the adoption of school legislation in 1996, the gradual systemic introduction of nine-year compulsory education got underway in Slovenia. The first interventions in the design, the legal solutions and the realisation of nineyear compulsory education occurred in 2001, when the solution for external testing or assessment of knowledge was changed. The ministerial team that prepared this solution failed to defend in public and in the profession the requirement that the grade obtained in the external assessment of knowledge should influence the successful completion of nine-year compulsory education. Soon after, the solution of the simultaneous descriptive and numerical assessment of knowledge in the second three-year period of compulsory education was also 
changed. There were even more significant interventions in the systemic solutions of nine-year compulsory education between 2005 and 2007 , when there were changes in the areas of external and internal assessment of knowledge, the partial external differentiation of students in the $8^{\text {th }}$ and $9^{\text {th }}$ grades, a reduction in the extent of selectivity, the abolition of general learning success, the introduction of the possibility of flexible organisation of the schedule, an attempt to introduce a second foreign language, etc. (Kovač Šebart, 2007a, 2007b, 2008; Kovač Šebart \& Štefanc, 2017a, p. 126). The changes in this period were no longer based on transparent, well-considered and substantiated conceptual reflection (Ibid.; Marjanovič Umek, 2008).

During this period, the National Assembly typically amended the Compulsory School Act by a shortened procedure, explaining that the interventions in the Act were less demanding, although the new solutions gradually changed the overall image and concept of nine-year compulsory education and the Act from 1996. Those responsible for school policy claimed that there was no need for a new White Paper, as the changes were minor and in line with the existing concept. However, that was not the case. The changes were conceptual and substantive in nature, and some were even in conflict with the principles and solutions of the first White Paper (Krek, 1995). Even the results of evaluation studies carried out until that time (e.g., Žagar et al., 2003), which were discussed by the Expert Council for General Education of the Republic of Slovenia (Kovač Šebart, 2007a, p. 16), did not support some of the subsequent legally established interventions in nine-year compulsory education. The proposals for change did not arise without the participation of the profession. An expert commission was established in 2005 to examine possible conceptual and organisational changes in compulsory education. Although the commission was made up of established experts, none of them, nor other experts in the field of education, publicly justified or defended the interventions and solutions, despite being subject to a great deal of criticism from the profession. It seems that the changes at that time were largely dictated by financial rationalisation, and were less due to research and evaluations of findings that would provide an answer as to whether appropriate goals had been established for compulsory education, and whether the systemic solutions and educational practice had enabled the achievement of these goals at all, and if so, how it had been enabled and whether this had taken place in all schools. The social-liberal orientation of school policy had been gradually replaced by a neoliberal orientation (Kovač Šebart, 2007b, p. 3; 2012, p. 3; Štefanc, 2012).

In 2009, at the beginning of the mandate of the then new government, there was prevailing agreement on the need for a new White Paper. A special 
group of experts (National Expert Group) was therefore appointed and work on the new document was complete within two years. Published in 2011, the White Paper (Krek \& Metljak, 2011) offered a renewed concept of compulsory education. It was understood that this would mark a break with the practice by which systemic solutions are subject to interventions that typically lack professional argumentation. School policy does not, however, seem to have been based on the new document, as even before the compulsory education solutions were discussed within the National Expert Group, the ministry responsible for education had already submitted a proposal for new compulsory education legislation for public discussion, that is, prior to the commencement of public debate on the proposal of the new White Paper (Kovač Šebart, 2011a, p. 3, 2011b, p. 3; Kovač Šebart \& Štefanc, 2017a). We believe this is one of the reasons why this document - in terms of the weight of its affirmation in the professional sphere - did not reach the level of the White Paper from 1995. The question arises as to whether this was in fact the purpose of school policy at the time.

The period that followed was not marked by major changes by the then ministerial team, at least not as far as public compulsory education was concerned, even though it was clear that compulsory school in particular needed to reflect on systemic solutions in terms of equity and equal educational opportunities as well as non-discrimination. The economic crisis and austerity measures, which severely affected vulnerable groups, were sufficient indications that some of the systemic solutions had already fallen victim to time, or that they were in need of thorough expert examination (Kovač Šebart, 2014, p. 17, 2016, 2016a; Kovač Šebart \& Štefanc, 2017b).

The subsequent ministerial team, too, failed to continue from the point where things had stalled in 2011. It wanted to prepare a new document, a new White Paper, but it was not in power long enough to adopt any of the important considerations and solutions. The most recent minister is in a more or less unfortunate position and lacks genuine support of the profession (with the possible exception of the medical profession). She is primarily contending with how to give the public the impression that there is nothing wrong with school in the time of COVID-19 (cf. Mlakar, 2020; Statement by Minister, 2020). In this regard, a number of studies have been conducted examining education during the period when schools were closed. The ministerial team has received numerous proposals as well as expert criticisms, to which it has not responded (for further information see Department of Pedagogy and Andragogy, 2020).

For years, we in Slovenia have failed to engage in a comprehensive expert treatment of systemic solutions from the point of view of ensuring justice, equal opportunities and non-discrimination, as well as moral education for tolerance, 
solidarity and human rights. We should have done, however, as schools face not only pedagogical problems, but increasingly serious social problems, which have intensified in Slovenia over the years and have recently become acute due in part to the objective circumstances of the pandemic. Distance learning and education have begun to gain ground, leading to less and less direct interaction between students and teachers, as well as between students themselves. This demands immediate reflection and systemic expert solutions regarding the formative aspect of teaching, teacher authority, the transmission and acquisition of knowledge, the assessment of knowledge, individualisation and differentiation, etc. We live in the time of a double social stratification event: some students in the $2019 / 2020$ school year (and due to the lack of appropriate systemic solutions the situation will be similar in the 2020/2021 school year if we conduct distance learning and education) were not provided with the basic conditions required to work for distance schooling; differences in the process (non-)implementation of lessons arose both between schools and between teachers in individual schools. Some teachers had the knowledge and the will to attempt to actually execute instruction at a distance, while others avoided this and mostly sent materials and assignments to students in online classrooms or by email, expecting students to solve them on their own. This caused additional inequalities between students partly due to differences in the economic, social and cultural status of their families, differences in their numbers and the associated conditions for working at home, differences in parents' work schedules and their ability to help children to acquire knowledge, etc. In the 2019/2020 school year, we also had to deal with deviations from the requirements and expectations concerning the criteria for assessing knowledge; the Minister's instruction was that the assessment of knowledge should be "kind" (Kuralt, 2020). In the new circumstances, there is a logical consequence that was to be (and will continue to be) expected: families with greater cultural capital and higher expectations regarding their children's knowledge worked with their children more and insisted on the expectations that school had been forced to abandon. The spiral of inequality, which is like a parasite on the basic postulates of public education, has therefore deepened further. School policy did not respond to this with systemic reflections and solutions that would enable the acquisition of a quality general education for all students and provide all students with equal opportunities to access instruction and knowledge in the completely changed school circumstances. This would undoubtedly require additional budgetary inputs (especially staffing reinforcements enabling individualisation and internal differentiation in the quality execution of distance learning and additional work with students who cannot rely on the help, knowledge and skills of their parents). 
Even in the years prior to the coronavirus, schools themselves had to accommodate the dissatisfaction of teachers and parents, and of the expert and general public, generated by the demands and hardships derived from the wider social environment (Kovač Šebart, 2016a) if they were to make any attempt to perform their two interrelated fundamental tasks, that is, knowledge transfer and the formation of an autonomous, critical and responsible personality. Although, for at least the last fifteen years, it has been declaratively accepted even on the EU level that a fair education system must ensure that educational outcomes are independent of socioeconomic background and other factors resulting in educational disadvantage (Biesta, 2010; Efficiency and equity, 2006; Gaber \& Marjanovič Umek, 2009), school policy has not engaged with this systematically. However, it should have: in order to be able to take strategic action, we need to know how the spiral of social inequality has grown stronger from kindergarten onwards; we need to know who is progressing and who is being left behind in the system we have built and dismantled over the last 25 years, and, above all, why this has occurred (Kovač Šebart \& Štefanc, 2017a, pp. 113114; Kovač Šebart \& Štefanc, 2017b). In this regard, the large differences between the best and worst students in schools, and between schools themselves in Slovenia, for instance, are unacceptable. In determining the causes of failure, there is a need to study the differences in performance by gender, social origin, educational level of parents, etc. Another dimension of study should focus on areas where differences emerge and address the so-called external context, which includes the issue of poverty, the expectations of parents and peers, differences in the length of schooling, quality of education, and the effects resulting from education: income, economic and social inequality, and social mobility (Gaber \& Marjanovič Umek, 2009; Gaber et al., 2012). It is not enough to ensure merely formally equal access to educational resources in the education system (which is at least questionable for the poor in Slovenia today, if we also consider - limiting ourselves to compulsory education - access to textbooks and workbooks, as well as to food, open-air school, the offer and implementation of compulsory elective courses, etc.). Consideration of the basic categories of exclusion and their reproduction in the education system must result in systemic solutions concerning material conditions and other circumstances and behaviours that do not in their point of departure "accept" the differences between children and especially not their increase, but instead reflect on these differences and on this basis create conditions for their reduction (Kodelja, 2006).

It seems that the circumstances brought about by the viral epidemic may even suit school policy quite well, as under the pretext of crisis measures it can leave the public school more or less alone in dealing with real social problems 
and social inequality (Kobal Tomc \& Črnak-Meglič, 2016; Kovač Šebart, 2014, 2016a, 2016b; Kovač Šebart \& Štefanc, 2017a, 2017b; Kovač Šebart, 2019), as there has been practically no response on the part of school policy to the justified warnings for years.

\section{Compulsory education and its curricular solutions}

In the second half of the 1990s, when the curricular reform of nine-year public compulsory education took place, Kroflic (1997) pointed out that the learning-goal and process orientation of national syllabi was a logical consequence of a watershed period during which the concept of the formal education framework changed: it began to be based on common values, with clear aspirations to respect the plurality of values in society and to establish a tolerant attitude towards this plurality.

In the curricular reforms, the schedule of subjects and national syllabi of compulsory education were prepared. They defined general and operational goals as well as standards of knowledge with examples of content through which teachers could achieve these learning goals and standards of knowledge (Kovač Šebart \& Krek, 2009, pp. 50-70). The conceptual logic - which, in accordance with the instructions prepared by the National Curriculum Council in 1996 (Instructions for the work of the subject, 1996), followed the national compulsory education syllabi adopted in 1998 - was based on a clear distinction between general learning objectives and operational learning objectives, as well as the standards of knowledge derived from the latter. In the national syllabi, the standards of knowledge were typically defined on two levels: the basic standards of knowledge were described as the knowledge that should be achieved by most students included in the programme in each individual grade (in some subjects this was also defined at individual levels of difficulty), while there was also a separate definition of minimum standards of knowledge, which described the knowledge that a student must demonstrate in order to be assessed positively, regardless of his or her personal circumstances, or the class or compulsory education that he or she attends (Ibid.).

Between 2006 and $2008,{ }^{3}$ without thorough professional consideration, a reconceptualisation of the national syllabi was carried out: in them, the standards of knowledge defined on the basis of operational learning objectives were replaced by the expected results derived from generally stated competencies

3 In accordance with Article 25 of the Organisation and Financing of Education Act (2007), the renewed national syllabi for compulsory education were determined by the Professional Council of the Republic of Slovenia for General Education at its $114^{\text {th }}$ session on 12 June 2008. 
supposedly based on key competences for lifelong learning. As Štefanc (2008, 2012) demonstrated, the changes reflected broader international processes closely related to aspirations for a comprehensive reconceptualisation of general education, which is becoming increasingly subjugated to demands and expectations for greater flexibility in the labour market. In this context, competencies serve as a conceptual tool to realise these expectations.

It should not be overlooked that on the arrival of virtually every new school ministerial team, the public receives the message that national compulsory education syllabi are too extensive, and that when the syllabi were created, as one minister said, "too little attention was paid to experts who could assess what a child is capable of at a certain age, for instance from the point of view of developmental psychology, or who could view the schedule of subjects as a whole" (Kovač Šebart, 2010). However, history shows that the facts are quite different: during the first post-independence national syllabi reform, the Compulsory Education Curricular Commission was headed by an internationally recognised expert in developmental psychology, who cannot be reasonably accused of failing to judge what a child is capable of at a certain age. Nor was she the only one on the commission. Moreover, we must not forget that the syllabi adopted in 1998 were reviewed in advance by teachers, who judged that the goals could be achieved and that the number of hours of the individual subjects allowed enough time to consolidate the material (New or renewed curricula, 1997).

We are not claiming that there is no need to review the syllabi of the time, as well as today's syllabi, in order to assess whether a reduction in the scope of learning goals is necessary. However, we will not be successful if, as a society, we address contradictory demands to those who prepare the syllabi, as well as to school, students and teachers. In the wider community, we must therefore first answer the question: What knowledge, and what kind of knowledge, is meaningful and necessary for our children? We therefore need a professional and political consensus on how we understand the quality general education of the younger generations (Kovač Šebart, 2016b). This is a problem that cannot be fully addressed by criticism of syllabi or teaching methods alone. The answer lies, at least in part, in a decision: Will we continue to understand general education in the community as a value in itself, as something we believe our young generations need because it fundamentally shapes and cultivates them, leading to an independence of reason that opposes prejudice, dogmatism, authoritarianism and arbitrariness? Will knowledge in itself therefore be a source of excellence worth striving for? Or, as a society, will we choose a different path whereby the knowledge with which we equip younger generations will become an increasingly functional, external factor, so that it is sufficient to merely learn 
how to use this knowledge? In the latter scenario, knowledge is indispensable as a tool, but we do not understand it as something that fundamentally shapes our personality (Ibid.; Gauchet, 2011; Kovač Šebart \& Kovač, 2018).

This decision will have consequences for the formation of young generations, as well as for the professional authority of teachers and for school as an institution that has traditionally opened the door to abstract knowledge. The two approaches and views lead to different formative effects on younger generations. Demands for students to see the sense of the knowledge they acquire in school, as well as its useful value or its applicability in understanding the world, are perfectly legitimate. The fact is, however, that an important part of general education is precisely in understanding the value of that which allows us to see beyond mere direct applicability, beyond knowledge that concerns everyday experience, to knowledge that opens our horizons and broadens our spirit. Knowledge that concerns general education is often "separate from the direct, local world of the learner" and requires "shifting interests away from the direct experience of the learner" (Oakeshott 1989 in Furedi 2016, p. 76).

It seems that in society today, we are already dealing with a prevailing, often unreflected view of knowledge: one the one hand, it must be relevant and directly applicable, while, on the other hand, there is no need for students to acquire it, as it is enough for them have it available at any time, at their fingertips (Gaber \& Tašner, 2017; Gauchet, 2011; Kovač Šebart \& Kovač, 2018). Moreover, at this point we cannot, without reflection, simply pass over the goal of "achieving international comparability of knowledge standards". In practice, this has been reduced to comparing the achievements of the international PISA survey, which examines the ability of 15 -year-olds to "face life's challenges", a phrase that can be translated as meaning especially being resourceful from the perspective of the needs of the labour market (Štefanc, 2008).

Unreflected and without safeguards from the point of view of the quality of compulsory education, we have followed the strategic documents of the European Commission, which state two priorities of EU member states: investing in young people and implementing the requirement for greater efficiency of the education system, both of which are primarily aimed achieving economic and social goals as well as EU competitiveness (A Budget for Europe, 2011, p. 28; Europe 2020, 2010, pp. 13-19). Meanwhile, the OECD (2017a) builds upon research findings (e.g., PISA, TIMSS, PIRLS) in order to enable countries to compare the knowledge, personality traits and skills of children and adolescents associated with lifelong learning and adult life outcomes on a global level, especially in the labour market (Ibid., p. 9). On this basis, countries are supposed to develop practical educational solutions that will facilitate the 
formation of citizens with developed abilities of "adaptation, ingenuity, respect and cooperation with others as well as personal and community responsibility" (OECD, 2017b, p. 1). Some Slovenian experts (Gaber et al., 2012) have pointed out the dangers of inappropriate conceptualisations in PISA research for education policies in national contexts, but they have been largely ignored. In documents (e.g., A Budget for Europe, 2011; Efficiency and equity, 2006; Europe, 2010, 2020; OECD, 2016, 2019) we therefore find almost no messages aimed at the process quality of the education system, or requirements that would establish the education of an autonomous, critical and responsible person with a quality general education at the forefront; we instead find an intention that Furedi (2016) calls soft engineering of the labour force.

If, in addition, we reinforce the belief in society that learning should always be easy, fun and playful, that it should immediately evoke feelings of pleasure, we should not be surprised by students' questions as to why they should learn content that is not directly useful, especially given the fact that the effort required by such learning is often experienced by students as an excessive burden (Kovač Šebart \& Krek, 2009, pp. 25-29; Kovač Šebart, 2016b; Kovač Šebart \& Kovač, 2018). We should therefore not be surprised that in today's society, "there is a very strong symbolic investment in school and school success, but this investment is accompanied by a more or less general disqualification of all activities that are a condition for acquiring knowledge. If we summarise this phenomenon in one formula: people want children to acquire knowledge without having to learn" (Gauchet, 2011; Kovač Šebart \& Kovač, 2018). Here we also see some of the reasons why pedagogical workers find it increasingly difficult to insist on demands that should be perfectly legitimate for school. School cannot solve this problem without the support of policy and the wider community, which will also address parents.

\section{The process level of the quality of compulsory education}

For decades, Slovenia has had neither adequate professional support nor systematic evaluation studies that would comprehensively answer questions about the process quality of compulsory education. As we have shown, school policies do not even reflect (or are not interested in) the fact that the formative process and effect of education are different if: (1) instruction follows and realises the goal of forming an individual capable of critical judgment and behaviour, with regard to which the knowledge acquired in school is understood as a value in itself, without always having a direct useful value, instead being a condition for the individual's understanding of the world and for his or her freedom and 
autonomy; or (2) we accept the concept of knowledge as a tool, we follow the conceptualisation of "learning to learn", and general education primarily serves the function of achieving the established economic and social goals and successfully adapting the individual to the labour market (Egan, 2009; Gauchet, 2011; Furedi, 2009).

In considering the process quality of compulsory education, it is important that with the post-independence curricular reform, we made the transition from syllabi based on learning content to syllabi based on learning goals. The professional autonomy of teachers was formally defined and the requirement for objectivity, criticality and pluralism was enshrined in legislation (Compulsory School Act, 2005; Organisation and Financing of Education Act, 1996). However, in the continuation in practice, from a procedural point of view, it seems that we have failed on several levels. This thesis is, of course, in need of verification: (1) national syllabi today are still often understood and read as if they were content-based; (2) instead of implementing the principles of criticality, objectivity and pluralism, the principle of common sense and judgment is asserted, which is based in part on the particular value judgments of individuals or the majority; and (3) professional autonomy is often just a phrase, as it requires taking responsibility for content planning of instruction that is linked to goals and standards of knowledge, that is critical towards untruths, beliefs, stereotypes and prejudices, and that builds on a plurality of arguments. It is foreign to professional autonomy to base teaching only on teaching aids prepared by textbook authors or colleagues, so that students learn only that which is written in textbooks, or to avoid addressing so-called controversial topics in the classroom and not be able to explain that the right of parents to raise their children in accordance with their beliefs does not mean that they can demand that certain content is not addressed at school; parents do, however, have every right to appeal if the instruction is indoctrinated, if it does not therefore adhere to the principles of criticality, objectivity and plurality. Also foreign to professional autonomy is the absence of reflection on how to achieve the fundamental goal of compulsory school education, which is the responsible, critical and autonomous individual (Kovač Šebart \& Krek, 2009; Kovač Šebart, 2017, 2019).

The process aspect of the quality of instruction does, of course, include much of that which fundamentally characterises school and requires systematic professional treatment and work with students, teachers and parents: from the expectations that students have when they enter school, to the expectations that teachers and parents have of students; from the establishment of teacher authority - which should not be confused with the authority associated with the place that the teacher occupies within the institution and with the power with 
which the teacher is endowed by the means of power at his or her disposal - to alliance with parents, whose demands must not interfere with the professional autonomy of the teacher, while the latter must not confuse authority with professional arbitrariness. In a democratic school, a parent or student can question the teacher when they do not know something or fail to understand something; this should even be desirable. The teacher must answer such questions professionally, as they fall within the domain of professional autonomy. The process aspect also includes reflection on how to enforce the rules and to ensure that students respect them, including the rules for which we prepare specific pedagogical strategies in schools. For the process dimension, it is also important to deal with the assessment of knowledge, which today already has an air of negativity: when we say that the student must learn for knowledge, not for grades, we ignore the fact that grades can be a means to an end, which is knowledge. The type and quality of the knowledge that students acquire largely depends on the criteria for assessing knowledge (Ibid.; Štefanc \& Kovač Šebart, 2020).

The process aspect of quality assurance in compulsory education has lacked adequate professional support at the systemic level for years. The first postindependence efforts in this regard established a framework for the evaluation of process quality (Pluško et al., 1999, 2001), but the policy efforts of that time focused primarily on the systemic solutions of nine-year compulsory education and their implementation, and there was insufficient time for content and process questions. There was no interest in this in the following years, either. The preparation of models for identifying and ensuring quality in the education system, which took place through projects (Design and introduction of a system, 2008; Establishment, supplementation, 2016), was for some time more focused on efficiency, that is, on student achievement in international research, as dictated by international financial organisations. Dealing with process quality is therefore completely left to schools and teachers, as it is assumed that it concerns professional autonomy. This is, of course, primarily an excuse so that the line ministry does not have to deal with it: to commission research to obtain feedback on the quality of teaching, learning and student knowledge, to seek and fund solutions.

Recently, the National Education Institute of Slovenia as well as some private institutions have been offering support to schools with projects of socalled formative monitoring (Štefanc \& Kovač Šebart, 2020, p. 16). Even in this case, however, considerations that would provide answers to questions regarding the quality of general education and the role of knowledge in the formation of the personality are not in the foreground.

In principle, we do not have any problems with goal-oriented instruction, but we are aware that one of its weaknesses can be a lack of interest in the 
process dimension of instruction. We are not saying that it does not make sense to set goals, but that it is important what these goals are and what role they play in processes of curricular planning, implementation and evaluation (Ibid.). Egelandsdal and Riese (2020), for instance, focus their criticisms of formative monitoring on its explicitly operational goal orientation: on the one hand, they report that it is simply not possible to transform all teaching objectives (especially formative, moral educational objectives) into objectively measurable effects of teaching and learning; on the other hand, they take issue with the specific and increasingly established notion of goals as learning outcomes in the function of educational efficiency. They draw attention to the danger of reducing formative monitoring to a mechanism for ensuring the effectiveness of education, and thus to activity driven more by striving to adapt the individual to the needs of the labour market than by the quality of knowledge.

In the Slovenian space, Peršolja (2020), for example, unlike Egelandsdal and Riese, even uses the argument of efficiency precisely to affirm formative monitoring: among other things, the author refers to a study of the cost-effectiveness of 22 approaches to learning (Yeh, 2011; Ibid.), which is supposed to demonstrate that the introduction of formative monitoring is the most costeffective approach in the long run, even in comparison with comprehensive school reform (Peršolja, 2020; for more on this, see Štefanc \& Kovač Šebart, 2020). The author expresses the value of formative monitoring "in economic terms" (Furedi, 2016, p. 45), and as such these terms certainly do not inhibit aspirations that lead to the devaluation of the meaning of knowledge as a value in itself. The question is therefore whether procedural efforts in the field of "formative monitoring" actually even support instruction and learning that establishes as its key goal the formation of an autonomous and free personality with an acquired general education that makes the individual capable of abstract critical reflection and behaviour (Štefanc \& Kovač Šebart, 2020), or whether these efforts actually support instruction that focuses primarily on facing life's "challenges" and on "self-regulation," due to which there is a significant risk that the process is focused primarily on "appropriate" - that is, efficient - skills of the "adapting and responding" of students "to new circumstances" (Ibid., p. 49). For further reflection, it is also important that within this logic we no longer speak about the assessment of knowledge; instead, aspirations are at work to assess the learning and "teaching" of education. As described by Biesta (2005, 2010, 2013) in several works, the teaching of education is reflected in "the rise of the concept of 'learning' and consequently the decline of the concept of 'education'. Teaching has thus become a support or promotion of learning, while education is increasingly described as providing opportunities for (experiential) learning" 
(Biesta, 2005, p. 55). This process takes issue with the transfer of knowledge that has arisen throughout human history and that should be acquired by generations of students. Knowledge is no longer understood as something that also needs to be transmitted, acquired and assimilated, as it must arise in a process of individual construction. Issue is therefore taken with the role of the teacher as someone who imparts knowledge and is responsible for the students' acquisition of knowledge, while "learning" is understood as the central point of all education and instruction. It therefore becomes important how students learn: whether they learn according to "contemporary" theoretical psychological notions of learning (e.g., learning to learn), or whether they also understand their learning and are able to "self-regulate" it, etc. (cf. also Biesta, 2010, 2013). "When we say that teachers should promote learning - which is a phrase that is not foreign to school policy literature - we are actually saying very little, if anything, as long as we do not define what students should learn and what the purpose of learning is" (Biesta, 2005, pp. 18-19). As Liessmann (2006) notes, such a requirement is, in substance and meaning, very close to the suggestion to start cooking without ingredients (Ibid., p. 35). A framework is established within which it is possible to ask more or less only "technical questions, that is, questions about the efficiency and success of the educational process. It is practically impossible to ask more important questions about the content and purposes of education" (Biesta, 2005, p. 59). This is an ideological constellation to which we have been constantly drawing attention in the present text and which, as we have already shown, enables instruction and learning in compulsory schooling to become a mechanism of the realisation of economic interests and to be formed according to the principles of the free market: the student becomes a (potential) consumer, who therefore has certain needs that the teacher or educational institution adequately meet (Ibid., p. 58).

\section{Concluding remarks}

At a time when the responsibility for distance education and children's schoolwork is largely shifted to parents, requiring them to make an effort that they did not feel (or to a significantly lesser extent) when the child attended compulsory instruction and that now represents a burden that many parents cannot manage, or can manage only with difficulty, parents are much quicker to ask themselves certain questions: Why does a child have to learn something? Why is there so much that is useless, so much ballast? If parents have become experts in teaching and learning with children overnight, and if this is perfectly acceptable and self-evident for policy, it is clear that parents will also 
take making judgments about what their child should know and what should be learned as a legitimate right. This is also true in terms of what parents are willing to take responsibility for on the level of the expectations that their child must meet with regard to schoolwork. Since parents are not experts on either of these matters, they are guided by messages from politicians and the public about useful knowledge, about the adequacy of a child in school learning to learn and implementing this when necessary. Not even school policy reflects on what constitutes quality in general education and what the consequences are for the formation of the individual if school opens its doors to spaces and dimensions that are not accessible and understandable to him or her in everyday life and through everyday experience. Should anyone therefore be surprised that parents and students are primarily interested in grades and certificates, and in the associated belief they bring regarding the wellbeing of the child's future?

With this, compulsory public school does, of course, lose the important role it has played in society; namely, to open the door to abstract knowledge for new generations. In school today, the interest of the learner is increasingly focused on the direct experience of the local world, causing us to reflect less and less, as Berger and Luckmann (1988) pointed out decades ago, that such experience contains "countless prescientific and quasi-scientific explanations of the everyday reality that is [for the individual] self-evident" (Ibid., p. 28). The knowledge acquired by new generations in compulsory education should be based on the intellectual legacy of humanity as a whole, and the fact is that this content often cannot be directly related to issues of interest to the child and student on a daily basis (Furedi, 2016, p. 173; Gauchet, 2011; Kovač Šebart \& Kovač, 2018; Kovač et al., 2020). We should always keep in mind the fact that there is no critical personality without critical thought, which is always argumentative thought: without understanding scientific knowledge and the functioning of social mechanisms, without assimilating the accumulated fruits of the human mind. Without knowledge that is acquired not only through experience, we are as a rule left only with thought based on negative criticism, that is, with people who act as dictated by the crowd or by a leader they trust, even though a critical appraisal would clearly indicate that there is no basis for this. At least in terms of formally established goals, school should still lead young generations in the direction of critical thinking. If we renounce this, we should not be surprised by hatred, exclusion and a lack of solidarity in society, which are among the range of prejudicial and stereotypical behaviours. These behaviours can only be opposed by internalised knowledge, the ability to make argumentative judgments, and formation on the basis of common values that students must acquire on the level of knowledge, feelings and actions. 
The paradox of the so-called knowledge society based on the logic of learning to learn, on a belief in the rapid obsolescence of the entire body of knowledge, and on the requirement that school focus on developing the ability to adapt to labour market requirements is that it is precisely broadly educated people possessing knowledge that has been accumulated throughout history who know how to respond well to the changes taking place in society and the labour market. They are capable of critical thinking that follows the general rules of argumentation and is strongly connected with an understanding of abstractness and abstract knowledge. It is true that these are typically not people with an unreflective and subservient flexibility at any cost; they are capable of responding to and resisting unacceptable demands placed on them by, for instance, employers and politicians. This is the price that society has to pay if school is to actually follow the aforementioned goal (Hočevar \& Kovač Šebart, 2018, pp. 15-16). In short, adaptation and success in the labour market in adulthood are not a problem at all if we follow the goal of quality general education, the acquisition of knowledge that does not only concern our interest, that does not always have immediate direct useful value, and if we form critical and autonomous personalities. As stated above, this can, however, be a problem for the bearers of social power if they expect conformism and obedience from people.

Only a critical analysis of the societal integration of the systemic solutions of compulsory education enables the demystification of some basic ideological formulas that repeatedly hegemonise the school ideological apparatus, as well as reflection on what these solutions serve, how they have developed, "what dangers and opportunities are associated with them, and what development it is reasonable to expect" (Pulliam \& van Paten, 1996, p. 2). The point of pedagogical theory is thus to clarify the place where the teacher and the student stand in a certain period (to use a metaphor) (cf. Močnik, 1985). If we do not explain the circumstances that determine this place, ideology works through us in such a way as to obscure the position that we could resolve. Its success is, of course, greatest when, through declaratively established goals, we insist on positions that objectively reproduce completely the opposite effects from those that are desired, and in so doing fail to notice, or perhaps even do not want to notice, that this is the case (Kovač Šebart, 2002, p. 234). 


\section{References}

A Budget for Europe 2020 - Part II: Policy fiches. (2011). European Commission.

Bahovec Dolar, E., Kodelja, Z., Marjanovič Umek, L., Zgaga, P., Kovač Šebart, M., Šimenc, M., \& Krek,

J. (1995). Načela in teoretična izhodišča [Principles and theoretical starting points]. In J. Krek (Ed.), Bela

knjiga o vzgoji in izobraževanju v Republiki Sloveniji (pp. 11-34). Ministrstvo za šolstvo in šport.

Barle Lakota, A., \& Bergant, K. (Eds.). (1997). Kurikularna prenova. Zbornik [Curricular renewal.

Proceedings]. Nacionalni kurikularni svet.

Berger, P. L., \& Luckmann, T. (1988). Družbena konstrukcija realnosti [The social construction of reality]. Cankarjeva založba.

Biesta, G. J. J. (2005). Against learning. Reclaiming a language for education in an age of learning.

Nordisk Pedagogik, 25(1), 54-66.

Biesta, G. J. J. (2010). Good education in an age of measurement: Ethics, politics, democracy. Taylor \&

Francis.

Biesta, G. J. J. (2013). The beautiful risk of education. Paradigm Publishers.

Compulsory school act [Zakon o osnovni šoli (ZOsn)]. (1996). Ur. l. RS, 12/1996.

Compulsory school act [Zakon o osnovni šoli (ZOsn-UPB2)]. (2005). Ur. l. RS, 70/2005.

Design and introduction of a system for determining and ensuring the quality of educational organisations (kindergartens and schools) [Zasnova in uvedba sistema ugotavljanja ter zagotavljanja kakovosti vzgojno-izobraževalnih organizacij (vrtcev in šol) - KVIZ]. (2008). http://kviz.

solazaravnatelje.si/

Egan, K. (2009). Zgodovina pedagoške zmote. Naša progresivistična dediščina od Herberta Spencerja do Johna Deweyja in Jeana Piageta [A history of pedagogical error. Our progressive heritage from Herbert Spencer to John Dewey and Jean Piaget]. Krtina.

Egelandsdal, K., \& Riese, H. (2020). Never mind the gap: Formative assessment confronted with Dewey's and Gadamer's concept of experience. European Journal of Education, 55(1), 91-104.

Efficiency and equity in European education and training systems. (2006). http://eur-lex.europa.eu/ legal-content/EN/TXT/?uri=CELEX:52006SC1096

Europe 2020. A strategy for smart, sustainable and inclusive growth. (2010). European Commission. Establishment, supplementation and pilot testing of the model of quality assessment and assurance in the field of education [Vzpostavitev, dopolnitev in pilotni preizkus modela ugotavljanja in zagotavljanja kakovosti na področju vzgoje in izobraževanja - OPK]. (2016). http://solazaravnatelje. si/index.php/dejavnosti/projekti/projekti-evropskega-socialnega-sklada/vzpostavitev-dopolnitevin-pilotni-preizkus-modela-ugotavljanja-in-zagotavljanja-kakovosti-na-podrocju-vzgoje-inizobrazevanja

Furedi, F. (2016). Zapravljeno: zakaj šola ne izobražuje več [Wasted: Why school is no longer educating]. Krtina.

Gaber, S., \& Marjanovič Umek, L. (2009). Študije (primerjalne) neenakosti [Studies of (comparative) inequalities]. Pedagoška fakulteta UL. 
Gaber, S., Cankar, G., Marjanovič Umek, L., \& Tašner, V. (2012). The danger of inadequate conceptualisation in PISA for education policy. Compare, 42(4), 647-663. https://doi.org/10.1080/03 057925.2012 .658275

Gaber, S., \& Tašner, V. (Eds.). (2017). Prihodnost šole v družbah dela brez dela [The future of school in societies of work without work]. Pedagoška fakulteta UL.

Gauchet, M. (2011). Znanje brez smisla? [Knowledge without sense?]. In M. C. Blais, M. Gauchet, \& D. Ottavi (Eds.), O pogojih vzgoje (pp. 55-109). Krtina.

Hočevar, A., \& Kovač Šebart, M. (2018). Skrb za učinkovitost predšolske vzgoje ali »mehki inženiring « delovne sile prihodnosti? [Concern for the effectiveness of preschool education or "soft engineering" of the future workforce?]. Sodobna pedagogika, 69(4), 6-29.

Inequality in Croatia: Inequalities in the education system report with policy recommendations [Nejednakost u Hrvatskoj: Nejednakosti u obrazovnom sustavu izvještaj sa policy preporukama]. (2016). Centar za mirovne studije.

Instructions for the work of the subject and programme curricular commissions [Navodila za delo predmetnih in programskih kurikularnih komisij]. (1996). Nacionalni kurikularni svet, Področna kurikularna komisija za osnovno šolo.

Jerončić, M. (2016). Reprodukcija društvenih nejednakosti u obrazovanju: obrazovna inkluzija dece romske nacionalnosti u Srbiji [Reproduction of social inequalities in education: The educational inclusion of Roma children in Serbia]. Interkulturalnost, 11, 55-67.

Kodelja, Z. (2006). O pravičnosti v izobraževanju [About justice in education]. Krtina.

Kobal Tomc, B., \& Črnak-Meglič, A. (Eds.). (2016). Situacijska analiza položaja otrok v Sloveniji (druga faza): končno poročilo [Situational analysis of the situation of children in Slovenia (second phase): Final report]. Inštitut Republike Slovenije za socialno varstvo.

Kovač, M., Kovač Šebart, M., Vidmar, T., \& Mažgon, J. (2020). Bralne navade v Sloveniji in bralne navade študentov pedagoških programov: je kovačeva kobila bosa? [Reading habits in Slovenia and reading habits of students of pedagogical programmes: Is the blacksmith's mare barefoot?]. Sodobna pedagogika, 71(2), 40-57.

Kovač Šebart, M. (1998). Načela in cilji vzgoje in izobraževanja - razprave o podstati našega šolskega sistema [Principles and goals of education - discussions on the basis of our school system]. Sodobna pedagogika, 49(1), 34-55.

Kovač Šebart, M. (1999). Diferenciacija v polju šolske prenove [Differentiation in the field of school renewal]. Sodobna pedagogika, 5o(1), 72-87.

Kovač Šebart, M. (2002). Samopodobe šole: konceptualizacija devetletke [Self-conceptions of school: A conceptualisation of a nine-year compulsory education]. Zavod Republike Slovenije za šolstvo, Znanstveni inštitut Filozofske fakultete.

Kovač Šebart, M. (2007a). Od papirnatega tigra do tigra brez papirja. Reformna pot slovenskega šolstva [From a paper tiger to a paperless tiger. The reform path of Slovenian education]. Sodobna pedagogika, 58(2), 6-33.

Kovač Šebart, M. (2007b). Merjeno z enakim vatlom? [Measured with the same ell?]. Šolski razgledi, 
58(11), 3 .

Kovač Šebart, M. (2008). Ne vedo, kaj spreminjajo! [They don’t know what they’re changing!] Šolski razgledi, 59(6), 3 .

Kovač Šebart, M. (2010). Minister “minus 20 odstotkov" [Minister “minus 20 percent”]. Šolski razgledi, 61(3), 3 .

Kovač Šebart, M. (2011a). Se zgodovina ponavlja? [Is history repeating itself?]. Šolski razgledi, 62(8), 3. Kovač Šebart, M. (2011b). Razprava po razpravi, ki je skoraj ni bilo [Debate after a debate that was almost non-existent]. Šolski razgledi, 62(12), 3.

Kovač Šebart, M. (2012). Srce boli, a obrezana drevesa (s)pomladi bolje cvetijo [The heart hurts, but pruned trees bloom better in the spring]. Šolski razgledi, $63(8), 3$.

Kovač Šebart, M. (2014, February 22). Čas zamujenih javnih razprav: desetletje devetletke [A time of missed public debates: A decade of nine-year compulsory education]. Dnevnik, p. 17.

Kovač Šebart, M. (2016a, July 30). Dolgoročno pravično izobraževanje [Long-term equitable education]. Dnevnik. https://www.dnevnik.si/1042747607/slovenija/sola-in-drzava-dolgorocnopravicno-izobrazevanje

Kovač Šebart, M. (2016b, September 24). Družba znanja? Ne me hecat!: šola [The knowledge society? Don’t pull my leg!: School.]. Dnevnik. https://www.dnevnik.si/1042751595

Kovač Šebart, M. (2017). Spoprijem z diskriminacijo in izključevanjem v javni šoli: med pravicami in pripoznanjem [Tackling discrimination and exclusion in public school: Between rights and recognition]. Sodobna pedagogika, 68(2), 10-32.

Kovač Šebart, M. (2019). Zdravi razum kot mesto boja za univerzalnost [Common sense as the place of a struggle for universality]. Sodobna pedagogika, 7o(2), 10-30.

Kovač Šebart, M., \& Kovač, M. (2018). Knowledge, values, equity: Contemporary tendencies in education. Dr. Kovač.

Kovač Šebart, M., \& Krek, J. (2009). Vzgojna zasnova javne šole [The educational design of the public school]. Pedagoška fakulteta UL.

Kovač Šebart, M., \& Štefanc, D. (2017a). Izobraževanje otrok [Education of children]. In A. ČrnakMeglič \& B. Kobal Tomc (Eds.), Položaj otrok v Sloveniji danes: situacijska analiza [The Situation of Children in Slovenia today: A situational analysis] (pp. 113-139). Inštitut RS za socialno varstvo. Kovač Šebart, M., \& Štefanc, D. (2017b). Toward greater equity in education through prudent conceptual solutions: Some empirical findings and systemic recommendations. In M. Sardoč, \& S. Gaber (Eds.), Fifty years of the Coleman report (pp. 195-218). Pedagoška fakulteta UL. Krek, J. (Ed.). (1995). Bela knjiga o vzgoji in izobraževanju v Republiki Sloveniji [White paper on education in the Republic of Slovenia]. Ministrstvo za šolstvo in šport.

Krek, J., \& Metljak, M. (Eds.). (2011). Bela knjiga o vzgoji in izobraževanju v Republiki Sloveniji [White paper on education in the Republic of Slovenia]. Zavod RS za šolstvo.

Kroflič, R. (1997). Učno-ciljno in procesno-razvojno načrtovanje kurikula [Learning-goal and process-development curriculum planning]. In Kurikularna prenova. Zbornik (pp. 197-201). Nacionalni kurikularni svet. 
Kuralt, Š. (2020, April 18). Ocenjevanje na daljavo ne more biti pravično [Remote assessment cannot be fair]. https://www.delo.si/novice/slovenija/ocenjevanje-na-daljavo-ne-more-biti-pravicno-30o148.html Liessmann, K. P. (2006). Theorie der Unbildung. Die Irrtümer der Wissensgesellschaft [Theory of noneducation. Errors of the knowledge society]. Paul Zsolnay Verlag.

Marjanovič Umek, L. (2008). Sprememb v vrtcu in šoli je veliko, strokovnih podlag zanje malo [Many changes in kindergarten and school, few professional bases for them]. Delo, 50(155), 21. Marjanovič Umek, L., \& Kovač Šebart, M. (1995). Zasnova osnovne šole [The design of compulsory education]. In J. Krek (Ed.), Bela knjiga o vzgoji in izobraževanju v Republiki Sloveniji (pp. 70-135). Ministrstvo za šolstvo in šport.

Mlakar, L. (2020, August 28). Ministrica Kustec: Novi virus nas v šolah ne bo več presenetil [Minister Kustec: The new virus will no longer surprise us in schools.]. https://siol.net/novice/slovenija/ ministrica-kustec-novi-virus-nas-v-solah-ne-bo-vec-presenetil-532744

Močnik, R. (1985). VRO je Ich - Ideal birokracije [VRO is Ich - The ideal of bureaucracy]. Problemi, $23(4), 34-36$.

New or renewed curricula for nine-year compulsory education [Novi oziroma prenovljeni učni načrti v devetletki]. (1997). Področna kurikularna komisija pri NKS.

Department of Pedagogy and Andragogy [Oddelek za pedagogiko in andragogiko]. (2020). Aktualno COVID-19 [The current COVID-19 situation]. https://pedagogika-andragogika.ff.uni-lj.si/aktualnocovid-19

OECD. Education policy outlook: Slovenia. (2016). https://www.oecd.org/slovenia/Education-Policy-

Outlook-Country-Profile-Slovenia.pdf

OECD. (2017a). Early Learning Matters. OECD.

OECD. (2017b). Study on social and emotional skills. http://www.oecd.org/education/ceri/OECD-

Study-on-Social-and-Emotional-Skills.pdf

OECD. Education at a glance: Slovenia. (2019). https://www.oecd.org/education/education-at-aglance/EAG2019_CN_SVN.pdf

Official data on the share of children with a delayed start of schooling [Uradni podatki o deležu otrok z odloženim začetkom šolanja]. (2020). Ministrstvo za izobraževanje, znanost in šport.

Organisation and financing of education act [Zakon o organizaciji in financiranju vzgoje in izobraževanja (ZOFVI)]. (1996). Ur. l. RS, 12/1996.

Organisation and financing of education act [Zakon o organizaciji in financiranju vzgoje in izobraževanja (ZOFVI-UPB5)]. (2007). Ur. l. RS, 16/2007.

Peršolja, M. (2020, May 15). Ko petica ne izmeri vsega znanja [When an 'A' does not measure all knowledge]. Dnevnik (pp. 14-15).

Pluško, A., Koren, A., Trtnik Herlec, A., Trnavčevič, A., Zupanc, D., Tkalčič, D., Lorenčič, I., Krek, J., Marjanovič Umek, L., Zorman, M., Kovač Šebart, M., Zupanc Grom, R., Gaber, S., Tkalec, V., Milekšič, V., \& Medveš, Z. (1999). Ugotavljanje in zagotavljanje kakovosti v vzgoji in izobraževanju: ravnatelji, osnovna šola [Determining and ensuring quality in education: Principals, compulsory education]. Ministrstvo za šolstvo in šport. 
Pluško, A., Koren, A., Trtnik Herlec, A., Trnavčevič, A., Zupanc, D., Tkalčič, D., Lorenčič, I., Krek, J., Marjanovič Umek, L., Zorman, M., Kovač Šebart, M., Zupanc Grom, R., Gaber, S., Tkalec, V., Milekšič, V., Vilič Klenovšek, T., \& Medveš, Z. (2001). Modro oko: spoznaj, analiziraj, izboljšaj: Ugotavljanje in zagotavljanje kakovosti v vzgoji in izobraževanju: 2001/2002 [Wise eye: Familiarise, analyse, improve: Identifying and ensuring quality in education: 2001/2002]. Zavod RS za šolstvo. Poverty and inequality in Bosnia and Herzegovina 2007-2011 [Siromaštvo i nejednakost u Bosni i Hercegovini 2007-2011]. (2015). http://documents1.worldbank.org/curated/zh/9761914680oo247821/ pdf/97643-REVISED-BOSNIAN-P132666-P152786-Box39319oB-bt-BiH-poverty-and-Inequality-inBiH.pdf

Pulliam, J. D., \& Van Patten, J. (1996). History of Education in America. Macmillan.

Statement by Minister Simona Kustec and official spokesman Jelko Kacin regarding the current state of the COVID-19 epidemic [Izjava ministrice Simone Kustec in uradnega govorca Jelka Kacina v zvezi z aktualnim stanjem epidemije bolezni COVID-19]. (2020, 19 May). https://www.gov.si/ novice/2020-05-19-izjava-ministrice-simone-kustec-in-uradnega-govorca-jelka-kacina-v-zvezi-zaktualnim-stanjem-epidemije-bolezni-covid-19/

Štefanc, D. (2008). Ideje neoliberalizma v procesih rekonceptualizacije obveznega splošnega izobraževanja: nekatere teoretske poteze in praktične implikacije [Ideas of neoliberalism in processes of the reconceptualisation of compulsory general education: Some theoretical features and practical implications]. Sodobna pedagogika, 59(3), 10-31.

Štefanc, D. (2012). Kompetence v kurikularnem načrtovanju splošnega izobraževanja [Competences in curricular planning of general education]. ZIFF.

Štefanc, D., \& Kovač Šebart, M. (2020) Nekaj razmislekov o razmerju med formativnim spremljanjem in ocenjevanjem znanja [Some reflections on the relationship between formative monitoring and knowledge assessment]. Sodobna pedagogika, 71(1), 10-31.

Universal declaration of human rights [Splošna deklaracija človekovih pravic]. (2018). Fakulteta za družbene vede and Ministrstvo za zunanje zadeve Republike Slovenije.

Vidmar, T. (2011). Šola in pojmovanja znanja med pragmatizmom in konstruktivizmom [School and conceptions of knowledge between pragmatism and constructivism]. Sodobna pedagogika, 62(1), $28-40$.

Žagar, D., Pečjak, S., \& Peklaj, C. (2003). Organizacija nivojskega pouka, stališča učencev, učiteljev in staršev do te oblike diferenciacije ter njeni učinki na učence: evalvacijska študija [The organisation of streamed lessons, the attitudes of students, teachers and parents towards this form of differentiation and its effects on students: An evaluative study]. Filozofska fakulteta Univerze v Ljubljani. 


\section{Biographical note}

MoJCA Kovač ŠEBART, PhD, is a full professor of Sociology of Education at the Faculty of Arts, University of Ljubljana, Slovenia. Her research topics include sociology of education, preschool and family education, authority, moral education, classroom and school culture, assessment in education, reading and textbook publishing.

DAmiJan ŚTEFAnc, PhD, is an associate professor in the field of didactics and curriculum studies at the Faculty of Arts, University of Ljubljana, Slovenia. His main research areas of interest are curriculum planning and instructional design at pre-primary, primary, general secondary, vocational and higher education. He is particularly interested in the theoretical and practical aspects of competence-oriented curriculum reforms which mainly affected the areas of iVET, general primary and secondary education.

TAdeJ Vidmar, PhD, is an associate professor in the field of history of education and comparative education at the Faculty of Arts, University of Ljubljana, Slovenia. His main research interests include all aspects of the theory and praxis of education in Slovenia in the 2oth century, development of the pedagogy as a science, as well as the concepts of the university in their historical and comparative dimension. 